УДК $631.42+665.61$

(C) 2014

\author{
Романович I. C., аспірант
}

(Науковий керівник - кандидат економічних наук М. С. Самойлік)

Полтавський національний технічний університет імені Юрія Кондратюка

\title{
ДОСЛІДЖЕННЯ СПЕЦИФІКИ ВПЛИВУ НАФТОВОГО ЗАБРУДНЕННЯ НА ЗМІНУ ФІЗИКО-ХІМІЧНИХ ПОКАЗНИКІВ ГРУНТУ
}

\section{Рецензент - доктор сільськогосподарських наук, професор П. В. Писаренко}

Експериментально досліджено основні показники проб трунту, забруднених сирою нафтою. Представлено результати зміни фізико-хімічних показників трунту внаслідок нафтового забруднення, проаналізовано вплив нафти на основні властивості трунту за різних рівнів концентрації полютанта в трунті. Зроблено висновки щцодо впливу нафти на якість та водорозчинну складову трунту. Проведено аналіз можливості впливу нафтового забруднення на грунтові води.

Ключові слова: фізико-хімічні показники, трунт, нафта, нафтопродукти, нафтове забруднення, вміст водорозчинних солей.

Постановка проблеми. Сучасне суспільство навіть за наявності науково-технічних досягнень використовує природні копалини як основне джерело енергії, а не поспішає замінити їх на альтернативні. Нафта - природний ресурс, який займає перше місце в світі у видобуванні, що створює одну 3 найгостріших проблем у сфері охорони навколишнього природного середовища. На сьогодні 3 видобутком, переробкою i транспортуванням втрачається від $0,1 \%$ до $16,5 \%$ нафти і нафтопродуктів, що становить близько десяти мільйонів тонн за рік, з яких до $20 \%$ потрапляє у Світовий океан, а інші 80 \% - у грунти і прісні водойми [6]. У грунті нафта спричинюе глибокі зміни основних фізикохімічних показників, перетворюючи його на непридатний для використання, в першу чергу, 3 сільськогосподарською метою [5]. Це ставить проблему забруднення грунтів нафтопродуктами на перше місце, адже Україна відома як агропромисловий край.

Аналіз основних досліджень і публікацій, у яких започатковано розв'язання проблеми. В процесі освоєння, облаштування та експлуатації родовищ нафти і газу в значній мірі змінюється природний ландшафт і йде інтенсивне забруднення земель. Грунтовий покрив - основний елемент ландшафту - першим приймає на себе «екологічний удар» [5].

В останні десятиліття виконувалося багато робіт, які висвітлювали ті чи інші аспекти пово- дження в природному середовищі забрудників, характерних для нафтовидобувного підприємства. Зокрема такими вченими як Т. І. Савкіна, М. Ю. Гілязов, Л. В. Стеровська і Н. П. Солнцева проведені природні дослідження закономірності процесів міграції-накопичення нафти та нафтопродуктів, моделювання в системі «грунт забрудник - доза - час - ефект», експериментальне моделювання нафтоємності, радіальної i латеральної проникності грунтів, динамічні спостереження еволюційних процесів і трансформацію грунтових вод [2, 8-10].

Зібрані дані показали, що своєрідне поводження забрудників у ландшафтах також пов'язане з особливостями техногенного впливу і специфікою вихідних властивостей грунту «стартових еталонів» [11]. Різноманітність «відповідей», характерних для основних типів грунтових тіл, що складають структуру грунтового покриву на територіях промислів, обумовлено біокліматичними й ландшафтно-геохімічними умовами - екзогенним потенціалом середовища. Дані залежності викликають необхідність вивчення як загальних закономірностей впливу нафти на ландшафти, так і специфічних, залежних від екзогенного потенціалу ландшафтів.

Саме тому метою нашої роботи було проаналізувати вплив нафти на основні властивості грунту за різних рівнів забруднення, оцінити характер погіршення грунтових властивостей та можливість погіршення якості грунтових вод.

Завдання: виконати комплексне дослідження проб грунту, забруднених сирою нафтою, експериментально визначити основні фізико-хімічні показники проб грунту.

Матеріали і методи досліджень. Для вивчення впливу нафтового забруднення на фізикохімічні показники грунту проведено ряд модельних експериментів. В якості об'єкта дослідження були відібрані проби грунту з сільськогосподарської ділянки с. Іванівка Карлівського району Полтавської області. В якості контролю використовували проби грунту без нафтових забруднень. В інших експериментах досліджували цю 
ж пробу із додаванням нафти в кількості, що відповідає концентрації 0,5 г/кг грунту, 4 г/кг грунту та 100 г/кг грунту. Таким чином було отримано три проби 3 різною концентрацією. Саме такі кількості нафтових забруднень було обрано згідно 3 європейським й українським стандартами та у випадку аварії відповідно з метою оцінки впливу мінімального забруднення, запропонованого європейськими та українськими природоохоронними службами й максимального забруднення.

Результати досліджень. Результати експериментального дослідження грунту представлені у таблиці «Основні фізико-хімічні показники чистої та забруднених проб грунту».

\section{Основні фізико-хімічні показники чистої та забруднених проб трунту}

\begin{tabular}{|c|c|c|c|c|}
\hline \multirow[b]{2}{*}{ Параметри проби грунту } & \multicolumn{4}{|c|}{ Значення, \%, мг, мекв. } \\
\hline & $\begin{array}{l}\text { незабруднена } \\
\text { проба грунту }\end{array}$ & $\begin{array}{c}\text { забруднена } \\
\text { проба грунту I } \\
(0,5 \text { г/кг) }\end{array}$ & $\begin{array}{c}\text { забруднена } \\
\text { проба грунту II } \\
(4 \text { г/кг) }\end{array}$ & $\begin{array}{c}\text { забруднена } \\
\text { проба грунту III } \\
(100 \text { г/кг) }\end{array}$ \\
\hline Вміст органічних речовин & $4,12 \%$ & $2,64 \%$ & $1,33 \%$ & $1,2 \%$ \\
\hline Вміст гумусу & $3,71 \%$ & $2,38 \%$ & $1,97 \%$ & $1,08 \%$ \\
\hline Вміст втрат за прожарювання & $13,62 \%$ & $14,31 \%$ & $14,22 \%$ & $17,94 \%$ \\
\hline Вміст мінеральної частини & $86,38 \%$ & $85,69 \%$ & $85,78 \%$ & $82,06 \%$ \\
\hline Значення обмінної кислотності & $\begin{array}{c}1,51 \text { мг/ } \\
0,151 \text { мекв }\end{array}$ & $\begin{array}{c}1,66 \text { мг/ } \\
0,166 \text { мекв }\end{array}$ & $\begin{array}{c}2,12 \text { мг/ } \\
0,212 \text { мекв }\end{array}$ & $\begin{array}{c}10,06 \text { мг/ } \\
1,006 \text { мекв }\end{array}$ \\
\hline рН водної витяжки грунту & 7,23 & 7,35 & 7,48 & 7,62 \\
\hline $\begin{array}{c}\text { Загальний вміст водорозчин- } \\
\text { них солей }\end{array}$ & 109,40 мг & 121,96 мг & 102,99 мг & 61,97 мг \\
\hline $\begin{array}{c}\text { Загальний вміст } \\
\text { гідрокарбонат-іонів }\end{array}$ & $\begin{array}{l}43,70 \text { мг/ } \\
0,72 \text { мекв }\end{array}$ & $\begin{array}{c}34,2 \mathrm{мг/} \\
0,56 \text { мекв }\end{array}$ & $\begin{array}{c}34,2 \text { мг/ } \\
0,56 \text { мекв }\end{array}$ & $\begin{array}{c}34,2 \text { мг/ } \\
0,56 \text { мекв }\end{array}$ \\
\hline Загальний вміст хлорид-іонів & $\begin{array}{l}16,91 \text { мг/ } \\
0,48 \text { мекв }\end{array}$ & $\begin{array}{l}16,98 \text { мг/ } \\
0,48 \text { мекв }\end{array}$ & $\begin{array}{l}16,98 \text { мг/ } \\
0,48 \text { мекв }\end{array}$ & $\begin{array}{l}16,98 \text { мг/ } \\
0,48 \text { мекв }\end{array}$ \\
\hline Загальний вміст іонів кальцію & $\begin{array}{l}12,00 \mathrm{мг/} \\
0,59 \text { мекв }\end{array}$ & $\begin{array}{c}4,00 \text { мг/ } \\
0,19 \text { мекв }\end{array}$ & $\begin{array}{c}4,00 \text { мг/ } \\
0,20 \text { мекв }\end{array}$ & $\begin{array}{c}4,00 \text { мг/ } \\
0,19 \text { мекв }\end{array}$ \\
\hline Загальний вміст іонів магнію & $\begin{array}{c}8,80 \text { мг/ } \\
0,72 \text { мекв }\end{array}$ & $\begin{array}{c}6,32 \text { мг/ } \\
0,52 \text { мекв }\end{array}$ & $\begin{array}{c}5,35 \text { мг/ } \\
0,44 \text { мекв }\end{array}$ & $\begin{array}{c}\text { 4,4 мг/ } \\
0,36 \text { мекв }\end{array}$ \\
\hline Загальний вміст іонів натрію & $\begin{array}{c}6,22 \text { мг/ } \\
0,27 \text { мекв }\end{array}$ & $\begin{array}{l}24,69 \text { мг/ } \\
1,07 \text { мекв }\end{array}$ & $\begin{array}{l}20,10 \text { мг/ } \\
0,87 \text { мекв }\end{array}$ & - \\
\hline Загальний вміст сульфат-іонів & $\begin{array}{l}13,61 \text { мг/ } \\
0,43 \text { мекв }\end{array}$ & $\begin{array}{l}35,77 \text { мг/ } \\
0,74 \text { мекв }\end{array}$ & $\begin{array}{c}22,36 \text { мг/ } \\
0,47 \text { мекв }\end{array}$ & - \\
\hline Загальний вміст нітрат-іонів & $\begin{array}{c}1,05 \text { мг/л/ } \\
0,017 \text { мекв }\end{array}$ & $\begin{array}{c}1,95 \text { мг/л/ } \\
0,032 \text { мекв }\end{array}$ & $\begin{array}{c}1,65 \text { мг/л/ } \\
0,027 \text { мекв }\end{array}$ & $\begin{array}{c}1,1 \text { мг/л/ } \\
0,018 \text { мекв }\end{array}$ \\
\hline Загальний вміст іонів заліза & $\begin{array}{c}1,19 \text { мг/Л/ } \\
0,021 \text { мекв }\end{array}$ & $\begin{array}{c}\text { 0,74 мг/Л/ } \\
0,013 \text { мекв }\end{array}$ & $\begin{array}{c}\text { 0,43 мг/л/ } \\
0,008 \text { мекв }\end{array}$ & $\begin{array}{c}\text { 0,33 мг/Л/ } \\
0,006 \text { мекв }\end{array}$ \\
\hline
\end{tabular}




\section{Висновки:}

1. Нафтове забруднення негативно впливає на фізико-хімічні, біологічні та іонообмінні показники грунту.

2. За малих концентрацій нафти в грунті збільшується вміст водорозчинних солей, що $\epsilon$ причиною процесів засолення грунту.

3. Взаємодія органічних сполук грунту з нафтою призводить до зменшення вмісту гумусової складової. Також ймовірне утворення комплексів органічних сполук із важкими металами, наявними в нафті.

4. У забруднених пробах грунту збільшується вміст нітрат-іонів, тому існує загроза потрапляння їх до першого та другого водоносних горизонтів.

5. У пробі №2 забрудненого грунту спостерігаються хімічні перетворення, внаслідок чого зменшуються втрати маси за прожарювання і не відбувається повної сорбції нітрат-іонів після додавання гумінових речовин. Дані перетворен-

\section{БІБЛІОГРІФІЯ}

1. Бирюков Н. С. Методическое пособие по определению физико-химических свойств грунтов / Н. С. Бирюков, В. Д. Казарновский, Ю. Л. Мотылёв. - М. : Недра, 1975. - 177 с.

2. Гилязов М. Ю. Изменение некоторых агрофизических свойств выщелоченного чернозема при загрязнении товарной нефтью в условиях Татарстана / Гилязов М. Ю. - Почвоведение, 2002. №12. - C. 1515-1519.

3. ГОСТ 18826-73. Колориметрический метод определения нитратов с сульфосалициловым натрием. - М. : Издательство стандартов. 1974. 8 c.

4. ГОСТ 4011-72. Вода питьевая. Метод определения общего железа. - М. : Издательство стандартов, 1982. - 9 с.

5. Гриценко А. И. Экология. Нефть и газ / А. И. Гриценко, Г. С. Акопов, В. М. Максимов. М. : Наука, 1997. - 598 с.

6. Давыдова С. Л. Нефть как топливный ресурс и загрязнитель окружающей среды / С. Л. Давыдова, В. И. Тагасов. - М. : Изд-во РУДН, 2004. - 131 с.

7. ДСТУ ISO 6059:2003 (ISO 6059-1984, IDT). Визначення сумарного вмісту кальцію та маг- ня свідчать про специфіку даного лісостепового ландшафту, зміненого під впливом сільського господарства.

6. У разі зростання концентрації нафти збільшується рН та значення обмінної кислотності.

7. Різке зниження ВРС у пробі №3 свідчить про блокування нафтою десорбційних центрів твердої фази грунту. У процесі приготування водної витяжки грунту спостерігається наявність гідрофобних макрокомпонентів.

8. В усіх пробах відбувається погіршення стану грунту, що викликає необхідність проведення заходів із відновлення їх якості.

9. У водорозчинних складових забруднених проб грунту відбуваються зміни, що можуть стати причиною погіршення стану грунтових вод.

10. Проблема деградації грунтів під впливом нафтового забруднення вимагає від компетентних галузевих служб прийняття негайних заходів, оскільки 3 грунтами пов'язана біологічна продуктивність усього ландшафту.

нію. Титрометричний метод із застосуванням етилендіамінтетраоцтової кислоти. - К., 2004. $6 \mathrm{c.}$

8. Етеровская JI. В., Яранцева Л. Д. О влиянии на растения загрязнений почвы при бурении и разведке на нефть и газ / Етеровская JI. В., Яранцева Л. Д. - Растения и промышленная среда. - К. : Наукова думка, 1976. - С. 73-75.

9. Савкина Т. И., Боярский 3. Г., Стынй 3. В. Повреждения почвы, вызванные загрязнением нефтью // Материалы Bсес. науч.-тех. конф. «Пробл. разраб. автом. сист. набл. контр. и оценки сост. окр. среды». - Казань, 1979. - С. 141143.

10. Солнцева Н. П., Гусеева О. А., Горячкин C. B. Моделирование процесов миграции нефти и нефтепродуктов в почвах тундры / Солнцева Н. П., Гусеева О. А., Горячкин С. В. - Серия «Почвоведенье». - №2. - ЕРТ : Вестн. Моск. ун-та., 1996. - С. 10-17.

11. Таргульян В. О. Общепланетарная модель экзогенеза и педогенез / Таргульян В. О. - В кн. «Успехи почвоведения». - М. : Наука, 1986. С. 101-108. 